\title{
Author Index Volume 1
}

F. S. Alves, A. P. Segatto \& E. De-Carli Theoretical

Framework About Relational Capability on

Inter-Organizational Cooperation

4 (2016) 1650012

Z. Bi see Kataev, M.

G. D. Bruton \& J. Chen Entrepreneurship Research in Asia:

2 (2016) 1650008

What We Know and Where We Move in the Future

1 (2016) 1650003

L. Bulysheva see Kataev, M.

L. Cai see Peng, X.

2 (2016) 1650008

4 (2016) 1650011

$\mathrm{Y}$. Cai see Peng, $\mathrm{X}$.

4 (2016) 1650011

H. Chen see Chen, Y.

2 (2016) 1650009

H. Chen see Chen, Y.

4 (2016) 1650013

J. Chen see Bruton, G. D.

Y. Chen \& H. Chen Innovation and Social Media: Cultural

1 (2016) 1650003 Impacts on the Opinion Influence Process in Brand Communities

4 (2016) 1650013

Y. Chen, F. Dong \& H. Chen Business Process and Information Security: A Cross-Listing Perspective

E. De-Carli see Alves, F. S.

2 (2016) 1650009

F. Dong see Chen, Y.

4 (2016) 1650012

2 (2016) 1650009

A. Emelyanenko see Kataev, M.

2 (2016) 1650008

B. Fan see Li, Y.

1 (2016) 1650001

H. Gao see Hisrich, R. D.

2 (2016) 1650006

Y. Gao see Peng, X.

4 (2016) 1650011

B. Ge see Hisrich, R. D.

2 (2016) 1650006

A. Gorkhali \& L. D. Xu Enterprise Application Integration in Industrial Integration: A Literature Review

4 (2016) 1650014

R. D. Hisrich, B. Ge, H. Gao \& F. Sheng Frontiers on Research of Innovation and Entrepreneurship: Review of the Keynotes of "The 2015 International Conference on Innovation and Entrepreneurship"

2 (2016) 1650006

M. Kataev, L. Bulysheva, A. Emelyanenko \& Z. Bi Enterprise Diagnostics for Evaluation of Enterprise Business Processes

2 (2016) 1650008 
J. Lei, B. Lin \& S. Sha Catching-Up Pattern Among Countries in Science-Based Industries: A Case Study in Pharmaceutical Industry

1 (2016) 1650004

Y. Li, Z. Luo, B. Fan \& J. Yin Who Is the Most Diligent Employee? A Discriminate Model for e-Government Service Time Analyzing

1 (2016) 1650001

R. Lima Economic Growth and Human Capital in the Post-Knowledge Era: A Focus on Positive Externalities and Spillover Effects of Knowledge in Italy and the Emergency of the Less Developed Areas

3 (2016) 1650010

B. Lin see Lei, J.

S. Lu see Peng, $\mathrm{X}$.

Y. Lu Industrial Integration: A Literature Review

Z. Luo see Li, Y.

X. Peng, L. Cai, S. Lu, Y. Cai \& Y. Gao Antecedent and Dimension of Symbiotic Relationship in the Hub-Based Entrepreneurial Ecosystem: Case Study of Alibaba

1 (2016) 1650004

4 (2016) 1650011

2 (2016) 1650007

1 (2016) 1650001

A. P. Segatto see Alves, F. S.

4 (2016) 1650011

4 (2016) 1650012

S. Sha see Lei, J.

1 (2016) 1650004

F. Sheng see Hisrich, R. D.

2 (2016) 1650006

S. Sundaresan \& Z. Zhang Knowledge Sharing and Learning in Organizations: Role of Incentives and Information Systems

3 (2016) 1650005

L. D. Xu see Gorkhali, A.

4 (2016) 1650014

J. Yin see Li, Y.

1 (2016) 1650001

Z. Zeng see Zhang, Z.

L. Zhang see Zhang, Z.

1 (2016) 1650002

1 (2016) 1650002

Z. Zhang see Sundaresan, S.

Z. Zhang, Z. Zeng \& L. Zhang Knowledge Expertise and Mass Amateurization on Internet-Based Knowledge Markets

3 (2016) 1650005

1 (2016) 1650002 